DOI 10.15826/qr.2016.4.196

УДК 821.161.1-311.2Достоевский+821.162.1-311.2Токаржевский

\title{
DOSTOYEVSKY AND TOKARZEWSKI: TWO SIDES OF THE SAME PLOT MODEL ${ }^{* * *}$
}

\author{
Alexander Shunkov \\ Kemerovo State University of Culture, \\ Kemerovo, Russia \\ Irina Yurtaeva \\ Kemerovo State University, \\ Kemerovo, Russia
}

The paper considers the correlation between two literary works about Siberian hard labour: F. Dostoyevsky's The House of the Dead and S. Tokarzewski's memoirs Seven Years of Hard Labour. The authors use a comparative method to identify the archetypes present in each work. They establish that the difference in the archetypes is predetermined by contrasting attitudes to the same labour camp: their opposed perceptions of the same plot are based on the mythologisation and demythologisation of prison respectively. The Polish patriot's view of his imprisonment in Siberia as nothing but cruel punishment which he endured with great courage resulted in a projection of martyrdom in his memoirs. The Russian writer's exile in Siberia, however, had a sacral significance in line with the Russian national tradition. Gaining new knowledge by passing through death becomes the mythological basis for the so-called "image from a distance" found in The House of the Dead. Its analytical plot is the main factor for regarding this text as a novel on the one hand, and part of the hagiographic tradition on the other.

Keywords: F. Dostoyevsky; The House of the Dead; history of $19^{\text {th }}$ century Russian literature; history of $19^{\text {th }}$ century Polish literature; S. Tokarzewski.

* This more detailed version of the article brings forward new arguments to refute the statement erroneously made by a number of Polish and Russian critics about the direct dependence of Fyodor Dostoyevsky's The House of the Dead on Szymon Tokarzewski's memoirs. The first observations on this issue were presented at a conference and then published in 2012 in Szczecin (Poland) [Shunkov, p. 134-139].

** Citation: Shunkov, A., Yurtaeva, I. (2016). Dostoyevsky and Tokarzewski: Two Sides of the Same Plot Model In Quaestio Rossica, vol. 4, № 4, p. 134-147. DOI 10.15826/qr.2016.4.196.

Цитирование: Shunkov A., Yurtaeva I. Dostoyevsky and Tokarzewski: Two Sides of the Same Plot Model// Quaestio Rossica. Vol. 4. 2016. № 4. P. 134-147. DOI 10.15826/qr.2016.4.196.

(C) Shunkov A., Yurtaeva I., 2016 Quaestio Rossica • Vol. 4 • 2016 • № 3, p. 134-147 
Рассматривается дискуссионная проблема соотношения произведений о сибирской каторге Федора Достоевского («Записки из Мертвого дома») и польского писателя XIX в. Шимона Токаржевского, проведшего в Сибири долгих семь лет («Семь лет каторги»). Используя сравнительно-типологический метод, авторы исходят из установки об оригинальности каждого литератора, сходство между произведениями которых предопределено условиями ссылки. Сопоставление произведений позволило обрисовать архетипические проекции каждого из рассматриваемых текстов. Различие их архетипов, по мысли исследователей, объясняется разным отношением к каторге, определяющим два противоположных восприятия одного сюжета, в основе которых - ее мифологизация и демифологизация. Польский патриот видел в поездке на каторгу в Сибирь только жестокое наказание, которое он вынес с мужеством борца. Поэтому жанровой проекцией мемуаров Токаржевского становится мученичество. Для русского писателя в соответствии с национальной традицией поездка в Сибирь приобретает сакральное значение. Получение нового знания, связанного с прохождением через смерть, составляет мифологическую основу «далевого образа» «Записок из Мертвого дома» Ф. Достоевского, поэтому аналитический сюжет этого произведения становится основным фактором, определяющим, с одной стороны, возможность романизации данного текста и, с другой, ориентацию темы «ухода» на традиции жития.

Ключевые слова: Ф. Достоевский; «Записки из мертвого дома»; история русской литературы XIX в.; история польской литературы XIX в.; мемуары; Ш. Токаржевский.

The history of world literature has seen dozens of works with similar plots. Such similarities between specific features have sometimes provoked an extremely negative reaction from those authors who strive for originality. An example is the quarrel between Ivan Turgenev and Ivan Goncharov over some similarities in their stories.

In the Russian and Polish literature of the $19^{\text {th }}$ century, two novels seem to be particularly close to one another: The House of the Dead by F. Dostoyevsky and Seven Years of Hard Labour by S. Tokarzewski. Both texts are based on the same plot, which is derived from the extra-textual reality: i. e., a certain degree of verisimilitude to the lives of the authors. Both suffered for their beliefs and were exiled to the same labour camp in Siberia: Tokarzewski for fighting for the independence of his motherland and sharing ideas of national revival and self-determination, and Dostoyevsky for his involvement in the Petrashevsky circle.

Fyodor Dostoyevsky (1821-1881, in prison from January 1850 to 1854) hardly needs an introduction. There has always been a great interest in his literary heritage in Poland. Its interpretation, however, has not been consistently unambiguous. Along with traditional works [Рудницкий] which acknowledge the writer's special philosophical and religious view of human nature, there are studies that make contradictory judgments in relation to both 
the author and his work. Yet, despite this polarity in Polish literary criticism [Wedemann; Скалинская], interest in Dostoyevsky is not in decline.

The name of the Polish writer Szymon Tokarzewski (1821-189(9?)), ${ }^{1}$ in prison from 31 December 1849) is only known to a narrow circle of readers because of its mention by Dostoyevsky in Part II of The House of the Dead, namely in Chapter VII, "Grievances", and Chapter VIII, "My Companions".

В сенях в кухне мне встретился Т-вский, из дворян, твердый и великодушный молодой человек, без большого образования и любивший ужасно Б. (Иосифа Богуславского. - А. Ш., И. Ю.). < .. > Его из всех других различали каторжные и даже отчасти любили. Он был храбр, мужественен и силен, и это как-то высказывалось в каждом жесте его [Достоевский, с. 446, 542-543].

Т-ский был хоть и необразованный человек, но добрый, мужественный, славный молодой человек, одним словом [Достоевский, с. 453] ${ }^{2}$.

The above quotes suggest that Tokarzewski and Dostoyevsky were personally acquainted: they bravely endured all the trials and hardships of exile in the Siberian prison and, on their return to normal life, both

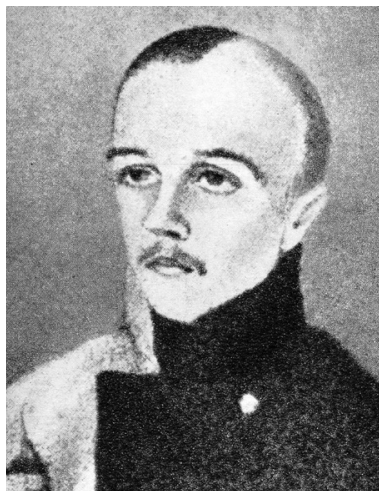

Szymon Tokarzewski (1823-1890). Muzeum Niepodległości w Warszawie committed their memories to paper. Both authors wrote about the same people and described similar situations, so it is not surprising that their stories bear some resemblance to each other. Despite this resemblance, however, which provoked an extremely negative reaction from the Polish writer and, later, some scholars and critics, these two works belong to fundamentally different typological models, which will be shown below via a comparative analysis.

It should be added that it was not until the beginning of the $20^{\text {th }}$ century that Tokarzewski's works were published in Poland for the first and only time [Tokarzewski, 1907, 1912, 1918]. In Russia, the first printed edition of his works appeared relatively recently, in 2007, thanks to two Siberian scholars from Kemerovo, Mary Kushnikova and Vyacheslav Togulev, who translated eight of his stories into Russian and provided some commentary [Кушникова, Тогулев]. This work received positive reviews from both Russian and Polish critics [Карпинский; Корнильцева].

However, certain statements quoted by Kushnikova and Togulev in the preface to the 2007 edition of S. Tokarzewski's works cannot but cause con-

${ }^{1}$ The data available suggests two different periodisations for Tokarzewski's life: 18211890 and $1821-1899$.

${ }^{2}$ In the ante-room I met T-vski, a young nobleman without much education, but of a firm, generous character; the convicts excluded him from the hatred they felt for the convicts of noble birth; they were almost fond of him; every one of his gestures denoted a brave and energetic man.

T-ski... though of little education, had an excellent heart; a worthy, very spiritual man. 
troversy. For example, some Polish researchers [Ungureanu; Pogonowski et al.]. consider Tokarzewski's Seven Years of Hard Labour a primary text and Dostoyevsky's The House of the Dead a secondary one. Pogonowski in particular argues that Dostoyevsky simply borrowed Tokarzewski's material as the basis for his novel. Below is an extract from Pogonowski's article. "The question about whether Dostoyevsky was likely to have plagiarised Tokarzewski's work could be answered in a doctoral thesis based on a study of the Russian and Polish archives. <...> The style and composition of Tokarzewski's memoirs, written in 1857, are very similar to those of The House of the Dead, and it is obvious that it was written before the book by Dostoyevsky describing the same events. These facts should be carefully examined: a Polish doctoral student could do this for their thesis" [Pogonowski].

Continuing his reasoning, Pogonowski gives the following explanation of the act allegedly committed by Dostoyevsky: in view of the fact that Tokarzewski was twice sentenced to hard labour, his copyright could easily be neglected. Another reason why the authorities would not have intervened in this matter was their special attitude to the Polish question. As a result, it is concluded that Dostoyevsky successfully played on nationalist sentiments in the 1850s and 1860s to take advantage of the situation for his own purposes. We believe that such an argument is unacceptable and even dangerous because rather than leading to the truth, it gives rise to a huge number of erroneous statements propounded by those who seek to make a name for themselves by all means possible, including rather ignoble ones.

In this regard, one cannot but wonder why modern scholars have ignored the article by Z. Bobowicz-Potocka "Who was the author of the chapter on Dostoyevsky in S. Tokarzewski's book Seven Years of Hard Labour?" [Bobowicz-Potocka, p. 91-94], published as early as 1975 and included in the notes for volume 3 [Достоевский, p. 205-482, 531-574, 543] of Dostoyevsky's Collected Works. The Siberian publishers Kushnikova and Togulev are no exception, although they note that V. A. Dyakov disagreed with Bobowicz-Potocka's hypothesis about the influence that Polish works about hard labour by Boguslavski and Tokarzewski had on Dostoyevsky's The House of the Dead [Tokarzewski, 2007, p. 75].

Our aim, however, is not to ascertain whether one writer used the existing material of the other to write his novel. Clearly, we are dealing with two completely different texts that interpret the same event. Reading them leaves no doubt about this.

A typological study of the plot of a novel is quite a difficult task due to the genre's fluidity and openness to "an unprepared, emerging and developing reality" [Бахтин, p. 451]. Just as difficult is the task of identifying typological similarities when analysing works with a less flexible genre structure whose development does not presuppose the violation of traditional canons. Therefore, of particular interest is studying a typology of plots in those genres whose form is less susceptible to transformation, such as notes, reminiscences, and memoirs. So, when comparing the works by Dostoyevsky and 
Tokarzewski, we should try to identify the difference between their views on the same world and the differences between their artistic techniques. "In this regard, the approach used by Kushnikova and Togulev does not seem entirely appropriate, as it focuses on drawing parallels between the texts and establishing points of apparent similarity. For instance, in the preface to $\mathrm{Si}$ birskoye Likholetye, the publishers give numerous examples of coincidences in the content of Dostoyevsky's and Tokarzewski's texts, thus unwittingly supporting the accusation of plagiarism The above parallels between the texts seem to prove that Tokarzewski was familiar with Dostoyevsky's The House of the Dead. However, this conclusion did not seem obvious to all researchers" [Кушникова, Тогулев, с. 74]. A bit later, however, the publishers give another version of this apparent similarity between the two completely different texts:

However, a detailed comparison of the texts above proves that Tokarzewski, describing similar conflicts, seems to provide extra material and correct Dostoyevsky rather than borrow from him [Токаржевский, 2007, с. 78] $]^{3}$.

Now arises a reasonable question: what could a convict see in his situation apart from his daily surroundings in prison? There is nothing unusual in the fact that both Dostoyevsky and Tokarzewski turned their attention to the same objects, people, and events. However, they emphasise different experiences. Witnessing the same events, their heroes exist on different artistic planes. So it would be misleading to mechanically take parts of one text and compare them with pieces from another which belongs to a different genre and then draw conclusions about similarities.

The genre of Dostoyevsky's The House of the Dead is characterised by a combination of "accurate descriptions of people and events and fiction", which was the reason why Dostoyevsky scholars regarded it as "bordering on an essay on the one hand, and memoirs on the other" [Чулков, с. 81]. We know that the writer was looking for a new form to express his views, which some critics describe as the features of a novel emerging from the traditional form of notes. For example, I. Mishin classifies The House of the Dead as a transition from "essays and notes to a socio-philosophical novel" [Мишин, с. 22].

The plot of The House of the Dead develops around comprehension of the world of the prison, gaining self-knowledge, and searching for the truth in general, which defines it as a novel. Yuri Lotman also considered it a novel [Лотман, с. 325-349].

Additionally, we could say that Tokarzewski's memoirs are comparable to the reminiscences of somebody who managed to survive in a Siberian prison and remain faithful to his beliefs. It therefore seems logical and understandable why the exiled Polish patriot is neither able nor willing to change his attitude to prison and other prisoners, seeing only their ugly side. Dostoyevsky regretted that the Poles only saw the convicts as brutes. For such a staunch fighter as Tokarzewski, changing his attitude towards

\footnotetext{
${ }^{3}$ Here in after the translation of quotes from scientific articles ours. - A. Sh., I. Yu.
} 
exile could mean only one thing - a departure from, or even betrayal of, his life's cause. So, despite broadening his horizons and expanding his experience, his position remained unchanged, which is why we can define the plot archetype of his memoirs as "martyrdom".

Our next argument is as follows: the examples given in the preface to the 2007 edition, impressive though they may be, cannot be used as evidence in a textual analysis of the two works. Literary scholars attach more importance to looking for citations, reminiscences, and allusions as proof of one text influencing another. None of those can be found in The House of the Dead, as Dostoyevsky and Tokarzewski wrote their texts for different reasons. Dostoyevsky's poetic style in The House of the Dead has been given the most thorough and comprehensive analysis. Scholars commonly find a Christian view of the world in all his novels, including the first one, Poor Folk (1848). Siberian exile convinced Dostoyevsky about Christianity's role as the path to salvation and about the need to find a spiritual way to "resurrect from the dead" through reading and comprehending the Gospel. In The House of the Dead, Dostoyevsky described his impressions of a four-year sentence, when some new significant concepts began to shape his worldview. The writer himself noted that these years in prison made him revise many of his former beliefs. In a letter to his brother on 22 February 1854, Dostoyevsky wrote: "The time has not been wasted as far as I am concerned. Even if I have not got to know Russia, I have got to know the Russian people well, perhaps better than many other people do". Therefore, The House of the Dead is a text based, first and foremost, on the Gospel tradition (parables of the prodigal son and the resurrection of Lazarus): this fact cannot be overlooked.

At the same time, The House of the Dead is part of literary traditions from the $19^{\text {th }}$ century, as it develops such themes as the people's role in history and the inconsistency, complexity, and duality of the soul of a Russian peasant ('muzhik'), which was common in the works of Dostoyevsky's predecessors and contemporaries such as Nikolai Gogol, Nikolai Nekrasov, Dmitry Grigorovich, Nikolai Uspensky, and Mikhail Saltykov-Shchedrin. In Russian culture, an exile to Siberia always carried some sacred meaning, which was predetermined by, firstly, the theme of trial (also present in Tokarzewski's memoirs), and, secondly, internal transformation through gaining self-knowledge and searching for truth. Furthermore, both texts deal with the subject of death, which explains a reference to Dante in both of them. Searching for the truth is the author's attempt to comprehend his new position. The gradual understanding of prison life determines the analytical development of the plot in The House of the Dead, resulting in the acquisition of new higher knowledge through the epistemological aspect of a myth - the discovery of truth through a descent into Hell and rebirth through illness and death.

Analysing plots of 'leaving' connected with Siberia, Yuri Lotman noted that "in a wide range of Russian stories, the plot sequence 'death - hell - resurrection' is replaced with 'crime - (real or imaginary) - an exile to Siberia - 
resurrection'. Moreover, the stay in Siberia is symmetrical to the denial of escape - return to Europe" [Лотман, c. 338]. Studying mythological models in literature on Siberian prisons (which play the role of the mythological moment 'death - a descent into hell') in connection with Nikolai Gogol's Dead Souls, Yuri Lotman identifies another, perhaps the most significant, element in the ternary mythological projection, i. e. resurrection: "Siberia is an extremely important point on the heroes' way" [Там же, с. 339]. He continues:... it is this plot that will be frequently repeated in the Russian novels of the $19^{\text {th }}$ century. Raskolnikov, Mitya Karamazov, Nekhlyudov, the characters of The Forged Coupon will commit a crime or realise the criminal nature of a 'normal' life, which will be viewed as the death of the soul. Then there will be an exile to Siberia (= death, hell) and subsequent resurrection. The mythological character of the 'Siberian episode' is made even more evident by the fact that the only novel where a hard labour camp is shown in a matter-of-fact light - The House of the Dead - does not have the element of resurrection, although the title equates Siberia with death [Там же].

However, it is the actualisation of a mythological model that makes it possible to consider this text a novel. Determined by the analytical development of the plot, this model is about searching for the truth and finding it.

The same connection of The House of the Dead with the Russian literary tradition was analysed by a famous literary critic Ilya Serman as early as the 1980s [Serman]. He noted that the 'dead house' was, nevertheless, inhabited by human beings with their 'souls and passions', and the narrator-memoirist (Aleksandr Petrovich Goryanchikov) seeks to understand their nature.

«Везде есть люди дурные, а между дурными и хорошие, - спешил я подумать себе в утешение, - кто знает? Эти люди, может быть, вовсе не до такой степени хуже тех, остальных, которые остались там, за острогом». Я думал это и сам качал головою на свою мысль, а между тем - Боже мой! если 6 я только знал тогда, до какой степени и эта мысль была правдой! [Достоевский, с. 267] .

The above example of the hero's reflections is in tune with the evangelical worldview: "And the light shineth in darkness; and the darkness comprehended it not" (John 1:5). Literary critics have repeatedly noted that Dostoyevsky nowhere else sought to create such a broad picture of the people's lives as in this novel. During his exile in Siberia, the writer also revised some of the ideas discussed in the Petrashevsky Circle, for which he had been sent to prison. His beliefs were now tested by the people, which led him to realise Russia's special way and create the theory of pochvennichestvo.

The memoirist Tokarzewski, however, never set himself such a goal. For the hero of Seven Years of Hard Labour, the world where he found himself

\footnotetext{
${ }^{4} \mathrm{Bad}$ people are to be found everywhere, but even among the worst there may be something good, I began to think, by way of consolation. Who knows? These persons are perhaps no worse than others who are free. While making these reflections I felt some doubts, and, nevertheless, how much I was in the right!
} 
is primarily an 'infernal abode' full of robbers, brigands, and villains who had lost their humanity. This perception of the world remains prevalent throughout the narrative.

Ani jednego z tych 2555 dni, spędzonych w Gehennie omskiej, nie można było nazwać «dniem dobrym!» [Tokarzewski, s. 150-151] ${ }^{5}$.

It seems as if there is always a border between the hero and the rest of the world, one which he is unwilling to overcome throughout the entirety of his term in prison. The hero and the world around him remain hostile to each other. Admittedly, his attitude to the world can be objectively justified because he is a victim suffering for his beliefs. Several episodes even create an impression of a degree of messianic exclusivity and the highly romantic nature of the hero.

Stanęliśmy przed tym krucyfixem:

- Przysięgnij chłopcze! - w uniesieniu mówił dziekan, - przysięgnij! Że tym szlakiem pójdziesz, jak owi «katorźnicy», których nazwiska czytałem przed chwilą. Podniosłem w górę prawicę i kładąc ją na nogach Chrystusowysh zawołałem:

- Na rany Ukrzyżowanego Zbawiciela przysięgam! [Tokarzewski, s. 10].

Aby odwiłżyć spiekłe usta, zerwałem garść trawy i gryzłem ją. Przykry smak goryczy wydał się mnie wróżbą, że również gorzkiem będzie całe moje życie [Tokarzewski, s. 62].

Tworzyliśmy przeto Apostolską liczbę. Prócz nas zbieraniny różnej, czyli tak zwanych «brygandów» było około siedemdziesięciu [Tokarzewski, s. 92-93].

Przyprowadzono nas do wrót tej piekielnej czeluści, gdzie lat siedem ze swego życia strawił... gdziem nieraz cierpiał ponad miarę sił ludzkich, a zkąd wyszedłszy mogłem z poetą zawołać: «Jak Dant za życia, przeszedłem przez piekło!» [Tokarzewski, s. 147] ${ }^{6}$.

\footnotetext{
${ }^{5}$ None of those 2,555 days lived in the Omsk Gehenna could be called a 'good day'!

${ }^{6}$ We stood in front of the crucifix.

- Swear to me, boy! - the dean said excitedly. - Swear that you will go the same way as those convicts whose names I read from the pulpit.

I put my right hand on Christ's feet and said:

- I swear by the wounds of the crucified Saviour!

To refresh my parched lips, I pinched some grass and began to chew it. The nasty taste of bitterness seemed to prophesy that my whole life would be just as bitter.

We were twelve in total - exactly as many as the apostles. Besides us were some rabble, so-called 'bandits' or brigands, numbering about seventy.

So, they led us to the gates of the infernal abode that swallowed seven years of my life... where I had to endure suffering beyond human power, so I could just as well exclaim like the poet: "Like Dante I walked through hell while still alive."
} 
Only the Siberian landscape can evoke some lyrical feelings and sheer delight in the hero.

Widzałem część naszych Karpat, lecz tak grożnie-pięknego, tak olbrzymio-wspaniałego położenia nie spotkałem nigdze. W tych górach jest coś, co człowieka wzrost przeraża i zadziwiał te wyniosłości sterczące, niby piramidy, wysokie, nagie, różnych form, różnych dziwacznych kształtów i postaci. Tutaj niby pochylona kolumna, zdaje się że lada chwila runie i odłamami swoimi pokryje wszystko, co się u stóp jej ściele.. dalej sterczy wyniosłość ogromna, niby głowa cukru spiczasta, u wierzchołka w olbrzymią ścięta płaszczyznę, podobną do półmiska, z którego parę tysięcy osób nakarmićby można do syta... [Tokarzewski, s. 108].

This description is probably one of very few examples that show the memoirist's favourable disposition towards the world around him. Siberian customs and traditions do not evoke any positive emotions, which is understandable considering how strange this world seems to him.

Yet, the hero of The House of the Dead has a different attitude to the surrounding world.

Вообще это было время моего первого столкновения с народом. Я сам вдруг сделался таким же простонародьем, таким же каторжным, как и они. Их привычки, понятия, мнения, обыкновения стали как будто тоже моими, по крайне мере по форме, по закону, хотя я и не разделял их, в сущности [Достоевский, с. 277] ${ }^{8}$.

Tokarzewski does not understand, and therefore does not accept, the truly Russian custom of giving alms to anyone in need or suffering. The chapter "The Disease" describes a case like this.

W głębokiej Rosji i w Syberyi skazańcom i katorżnikom lud okazuje wiele współczucia i obdarowywa ich jałmużną, przyjmowaną chętnie. «Nieszczastnyj!» oto miano, którem lud rosyjski nazywa katorżnika, a wciskając mu w rękę bądż bułkę pszenna, bądż kopiejkę, czy pół kopiejki mówi:

- Przyim mój podarek i niechaj Christus opiekuje się tobą, nieszczęśliwy!

Mnie to pozdrowienie wydało się miłości chrześciańskiej pełnem...

Możeby to lepszy był taki ustój społeczeństwa, kiedyby na zbrodniarza patrzo-

${ }^{7}$ I have seen some of our Carpathians, but I could never imagine such an awesomely beautiful, magnificent spectacle. There is something in these mountains that attracts and simply bewitches a human. These heights, landslides, pyramids, tall, bare, of different shapes and peculiar appearance; a tilted column looking like it is about to fall, its fragments covering all around it, then a sort of a sugarloaf with a pointed top, and also something like a basin, big enough to feed thousands of people to the full. $<\ldots>$ Looking at the mountains, one can't help wondering what almighty hand created this heap in such a deserted place, and yet in such a perfect harmony.

${ }^{8}$ I was very much astonished by all this, above all at the outset, during my first relations with this world. I became as low as my companions, as much a convict as they. Their customs, their habits, their ideas influenced me thoroughly, and externally became my own, without affecting my inner self. 
no, jak na człowieka, każdą inną niedołą dotkniętego? Ilekroć do mnie ktoś zbliżał się z jałmużną wołałem zdaleka.

- Dziękuję! Ja nie jestem «nieszczastnyj, no politiczeskij priestupnik».

Powtarzałem to wielokrotnie przez siedem lat, mniemam więc, że w końcu mieszkańcy Omska nauczyli się odróżniać zbrodniarzy od więżniów stanu [Tokarzewski, s. 197-198]'.

The House of the Dead also has an episode about giving alms.

На, «несчастный», возьми Христа ради копеечку! - кричала она [девочка], забегая вперед меня и суя мне в руки монетку. Я взял ее копеечку, и девочка возвратилась к матери совершенно довольная. Эту копеечку я долго берег у себя [Достоевский, с. 222 $]^{10}$.

The above examples show the different reactions of the heroes to a gesture of human compassion: in the same situation, the first hero refuses it while the second accepts it. Their understanding of their place in this world also varies. Belonging to a different paradigm of spiritual and cultural values, Tokarzewski cannot understand the symbolic and, to some extent, sacred meaning of the given gesture as a means of salvation and communion with the world.

It is impossible to imagine an opposition between the hero and the world in Dostoyevsky's artistic vision. In the first month of imprisonment, the hero of The House of the Dead feels fear and terror ("The present, meanwhile, was terrible enough"), but then he tries to find the strength to live in this world ("I felt obliged of my own accord to go to work in order to measure at one stroke the whole extent of my misfortune, that I might at once begin to live like the others, and fall with them into the same abyss") [Достоевский, с. 81].

Недаром же весь народ во всей России называет преступление несчастием, а преступников несчастными. Это глубоко знаменательное определение. Оно тем более важно, что сделано бессознательно, инстинктивно [Достоевский, с. 254] ${ }^{11}$.

\footnotetext{
${ }^{9}$ Russians living in the depths of the country and in Siberia feel a lot of sympathy for homeless people and convicts, endowing them with alms which they willingly accept.

- Poor man! - This is how Russian people call convicts and then slip a millet loaf or a kopeck, or even half a kopeck, into their hands saying:

- Take my alms and may Jesus bless you, poor you!

It sounded truly Orthodox to me...

However, when I saw someone coming towards me with alms, I shouted from afar:

- Thank you, but I am not a 'poor man', I am a political criminal.

I kept repeating that all seven years and it seems that, in the end, the residents of Omsk learned to distinguish vagrants and brigands from prisoners of a very different kind.

10 "Here, poor man," she said, "take this in the name of Christ." I took the money which she slipped into my hand. The little girl returned joyfully to her mother. I preserved that kopeck for a considerable time.

${ }^{11}$ Is it not known that the common people throughout Russia call crime a 'misfortune', and the criminal an 'unfortunate'? This definition is expressive, profound, and, moreover, unconscious, instinctive.
} 
Understanding a crime as an act leading to repudiation of, and separation from, the world (both divine and human) is a theme that runs through several works by Dostoyevsky, starting with The House of the Dead. Here, the author consistently leads the hero along the path of spiritual rebirth, beginning with such seemingly inconspicuous acts as the joyful acceptance of alms. It is noteworthy that an understanding of a Siberian prison can develop in typologically different structural and semantic variants of 'the plot of leaving'. In The House of the Dead, it has the sacred meaning of finding faith.

However, a labour camp remains a place of punishment: not every convict can view it in the light described above. Therefore there are other ways of interpreting the Siberian exile, as we see in Tokarzewski's case.

Continuing to compare the two texts, we cannot but see that they differ in their modes of narration. At first glance, both have features of memoirs, e. g., narration in the first person by a participant or a witness of the events. Seven Years of Hard Labour is a perfect example of this genre. The author uses a simple mode of narration and no complex techniques. The narrator is placed at the centre of narration, his opinion and judgment of the events being dominant.

Dostoyevsky's novel has a completely different, more complex structure. It is based on dialogue, a common feature of his poetic style. Therefore, it would be unjustified to compare the two texts in the way that the preface to Sibirskoye Likholetye does, i. e., comparing only formal aspects of the plots without analysing their inner form.

Another difference between the two works is their composition. Most arguments given by scholars in support of identity between them tend to be formalistic. The authors of the preface to Sibirskoye Likholetye are no exception when identifying literary parallels. At first glance, both Dostoyevsky and Tokarzewski composed their texts as an essay: however, the latter's composition is quite simple and linear.

The composition of The House of the Dead has been frequently analysed. We can only add that Dostoyevsky's text is built in such a way as to show the path of the hero's spiritual transfiguration through the atonement of guilt. Both parts of the novel can prove this. Part I is a "portrait gallery" of convicts with a climax in Chapter X, "The Christmas Holidays", where the convicts are shown in a different light, excited about the greatness of the holiday. Interestingly, this chapter comes after the description of the convicts' taking a bath, a symbol of hell where the narrator finds himself.

Когда мы растворили дверь в самую баню, я думал, что мы вошли в ад... Это было пекло. Всё орало и гоготало [Достоевский, с. 317-318] ${ }^{12}$.

\footnotetext{
${ }^{12}$ The steam became thicker and thicker every minute, so that what one now felt was not a warm but a burning sensation, as from boiling pitch. The convicts shouted and howled to the accompaniment of the hundred chains shaking on the floor.
} 
The symbolic episode of taking a bath conveys an idea of cleansing: although here it refers to the flesh only, it is a necessary step for the purification of the hero's soul. The illness the hero gets right after Christmas opens new prospects in his life. Quite remarkable is the compositional technique used here, a sequence of three important points in the plot: the convict's appeal in a prayer ("Lord Jesus Christ, have mercy on us!"), the hero's reflections at the end of Part I ("Well, I am not here for ever, but only for a few years!"), and a reference to the hero's illness at the beginning of Part II. As is well known, Part II is a philosophical reflection on the theme of punishment supported by artistic scenes. Finally, the novel ends with the hero's release, which can be interpreted as a symbol of his complete spiritual rebirth, resurrection, and acceptance of the world: "Yes, farewell! Liberty! New life! Resurrection from the dead! Unspeakable moment!" All this proves that the composition of The House of the Dead has nothing in common with that of Seven Years of Hard Labour. Moreover, it became a prototype for the composition of Crime and Punishment, the next novel by Dostoyevsky.

We believe that any further attempts to prove the originality of these two different texts that belong to different genres would be superfluous: accusing Dostoyevsky of borrowing someone else's material is just absurd. Even if we concede that Dostoyevsky may have used Tokarzewski's material (which seems unlikely), ${ }^{3}$ The House of the Dead should be regarded as artistic interpretation, which is totally different from plagiarism. After all, who would accuse Leo Tolstoy of plagiarising the notes of S. P. Zhikharev, who was at the reception organised by the Moscow nobility in honour of General Bagration, for use in War and Peace? [Жихарев, с 196-197].

Thus, the conducted research, on the one hand, once again has shown the relevance of problem "Dostoyevsky and Polish literature" which continues to be demanded as in Russian philology, and in Polish. And on the other hand, the research has shown absolute independence of two works belonging to different authors. Dostoyevsky and Tokazhevski can't be balanced among themselves in any way. Each of them belongs to different national cultural traditions for conceptualizing the issue of suffering and punishment. Convincing proofs for poetic distinctions of two works of the Russian and Polish writers are provided in article, which should be noticed.

\section{Список литературы}

Бахтин М. М. Вопросы литературы и эстетики. М. : Худож. лит., 1975. 504 с. Достоевский Ф. М. Собрание сочинений : в 15 т. Л. : Наука, 1988. Т. 3.573 с.

Жихарев С. П. Записки современника / ред., ст., коммент. Б. М. Эйхенбаума. М. ; Л. : Изд-во АН СССР, 1955. 836 с.

Карпинский М.. Сибирь - общее историческое пространство // Новая Польша. 2009. № 2. URL: http://www.novpol.ru/index.php?id=1109 (дата обращения: 23.01.2016).

Корнильиева И. Польская «Сибириада» // Европа. Ru. 2008. № 46. С. 9-10. URL: http://www.gazetarosyjska.pl/pliki/0046.pdf (дата обращения: 23.01.2016).

3 There is a statement on p. 281, vol. 4 of the Complete Works in 30 Volumes, that Tokarzewski borrowed a few episodes from Dostoyevsky; Tokarzewski's memoirs were published after Dostoyevsky's death. 
Кушникова М., Тогулев В. Предисловие к «Сибирскому лихолетью» Шимона Токаржевского // Токаржевский (Токажевский) Ш. Сибирское лихолетье / пер. с польск. М. Кушниковой ; сост. и авт. предисл. М. Кушникова, В. Тогулев. Кемерово : Кузбассвузиздат, 2007. С. 5-99.

Лотман Ю. М. Сюжетное пространство русского романа ХІХ столетия / Лотман Ю. М. В школе поэтического слова : Пушкин. Лермонтов. Гоголь: М. : Просвещение, 1988. 352 с.

Мишин И. Т. Художественные особенности «Записок из Мертвого дома» Ф. М. Достоевского / Уч. зап. Армавир. пед. ин-та. 1962. Т. 4. Вып. 2. С. 21-42.

Рудниикий Д. Вокруг Достоевского // Новая Польша. 2008. № 11. URL: http://www. novpol.ru/index.php?id=1064 (дата обращения: 23.01.2016).

Серман И. Тема народности в «Записках из Мертвого дома». URL: http://sites.utoronto.ca/tsq/DS/03/101.shtml (дата обращения: 23.01.2016).

Скалинская E. Достоевский глазами поляков : О книге Марека Ведемана «Полонофил или полонофоб? Федор Достоевский в польской словесности. 1847-1897»// Новая Польша. 2011. № 5. URL: http://www.novpol.ru/index.php?id=1488 (дата обращения: 23.01.2016).

Токаржевский (Токажевский) Ш. Сибирское лихолетье / пер. с польск. М. Кушниковой ; сост. и авт. предисл. М. Кушникова, В. Тогулев. Кемерово : Кузбассвузиздат, $2007.980 \mathrm{c}$.

Чулков Г. Как работал Достоевский. М. : Совет. писатель, 1939. 340 с.

Шунков А. В. Шимон Токаржевский и Федор Достоевский: два взгляда на один мир («Семь лет каторги» и «Записки из Мертвого дома») // Homo Communicans: человек в пространстве межкультурных коммуникаций / под ред. К. Янашек, Й. Митурской-Бояновской, Р. Гаваркевича. Щецин : Volumina.pl Daniel Krzanowski, 2012. C. $134-139$.

Bobowicz-Potocka Z. Kto byl wlasciwym autorem rozdzialu poswieconego Dostojewskiemu w ksiazce Sz. Tokarzewskiego «Siedem lat katorgi» // Przeglad humanistyczny. 1975. № 8. S. 91-94.

Muzeum Niepodległości w Warszawie. URL: http://muzeum-niepodleglosci.pl/xpawilon/szymon-tokarzewski/ (dostęp: 02.11.2016).

Pogonowski I. C. Czy Dostojewski wybił się plagiatem pamietnika Tokarzewskiego? URL: http://zaprasza.net/a_y.php?article_id=6239 (dostęp: 23.01.2016). $225 \mathrm{~s}$.

Tokarzewski S. Siedem lat katorgi. Warszawa : L. Biliński i W. Maślankiewicz, 1907.

Tokarzewski S. Katorznicy. Warszawa : L. Biliński i W. Maślankiewicz, 1912. 213 s. $240 \mathrm{~s}$.

Tokarzewski S. Siedem lat Katorgi. Warszawa : L. Biliński i W. Maślankiewicz, 1918.

Ungureanu $R$. Russian Imperial Presence in Literature. URL: http://www.ruf.rice. edu/ sarmatia/407/272ungure.html (dostęp: 23.01.2016).

Wedemann M. Polonofil czy polakozerca? Fiodor Dostojewski w pismiennictwie polskim lat 1847-1897. Poznan : Wydawnictwo Poznañskie, 2010. S. 23-29.

\section{References}

Bakhtin, M. M. (1975). Voprosy literatury $i$ estetiki [Issues of Literature and Aesthetics]. 504 p. Moscow, Khudozhestvennaya literatura.

Bobowicz-Potocka, Z. (1975). Kto byl wlasciwym autorem rozdzialu poswieconego Dostojewskiemu w ksiazce Sz. Tokarzewskiego "Siedem lat katorgi”. In Przeglad humanistyczny, 8, pp. 91-94.

Chulkov, G. (1939). Kak rabotal Dostoyevsky [The Way Dostoyevsky Worked]. 340 p. Moscow, Sovetsky pisatel'.

Dostoyevsky, F. M. (1988). Sobranie sochineny : v 15 t. [Collected Works, 15 Vols.]. Vol. 3. 573 p. Leningrad, Nauka.

Karpinsky, M. (2009). Sibir' - obshchee istoricheskoe prostranstvo [Siberia a Common Historical Space]. In Novaya Pol'sha, 2. URL: http://www.novpol.ru/index. php?id=1109 (mode of access: 23.01.2016).

Kornil'tseva, I. (2008). Pol'skaya "Sibiriada" [Polish Sibiriada]. In Evropa.Ru, 46, pp. 9-10. URL: http://www.gazetarosyjska.pl/pliki/0046.pdf (mode of access: 23.01.2016). 
Kushnikova, M. (Transl.) \& Togulev, V. (Comp., Foreword). (2007). Predislovie k "Sibirskomu likholet'yu" Shimona Tokarzhevskogo [Preface to Siberian Troubled Times of Shimon Tokarzewski]. In Tokarzhevsky (Tokazhevsky), Sh. Sibirskoe likholet'e (pp. 5-99). Kemerovo, Kuzbassvuzizdat.

Lotman, Yu. M. (1988). Syuzhetnoe prostranstvo russkogo romana XIX stoletiya [The Plot Space of the $19^{\text {th }}$ Century Russian Novel]. In Lotman, Yu. M. V shkole poeticheskogo slova : Pushkin. Lermontov. Gogol'. 352 p. Moscow, Prosveshchenie.

Mishin, I. T. (1962). Khudozhestvennye osobennosti "Zapisok iz Mertvogo doma" F. M. Dostoevskogo [The Artistic Features of The House of the Dead by F.M. Dostoyevsky]. In Uchenye zapiski Armavirskogo pedagogicheskogo institute, Vol. 4, Iss. 2, pp. 21-42.

Muzeum Niepodległości w Warszawie. URL: http://muzeum-niepodleglosci.pl/xpawilon/szymon-tokarzewski/ (mode of access: 02.11.2016).

Pogonowski, I. C. (n.d.). Czy Dostojewski wybit się plagiatem pamietnika Tokarzewskiego? URL: http://zaprasza.net/a y.php?article_id=6239 (mode of access: 23.01.2016).

Rudnitsky, D. (2008). Vokrug Dostoevskogo [Around Dostoyevsky]. In Novaya Pol'sha, 11. URL: http://www.novpol.ru/index.php?id=1064 (mode of access: 23.01.2016).

Serman, I. (n.d.). Tema narodnosti v "Zapiskakh iz Mertvogo doma" [The Theme of Volkstum in The House of the Dead]. URL: http://sites.utoronto.ca/tsq/DS/03/101.shtml (mode of access: 23.01.2016).

Shunkov, A. V. (2012). Shimon Tokarzhevsky i Fedor Dostoyevsky: dva vzglyada na odin mir ("Sem' let katorgi" i "Zapiski iz Mertvogo doma") [Szymon Tokarzewski and Fyodor Dostoyevsky: Two Views of One World (Seven Years of Hard Labour and The House of the Dead)]. In Yanashek, K., Miturskaya-Boyanovskaya, Y. \& Gavarkevich, R. (Eds.). Homo Communicans: chelovek v prostranstve mezhkul'turnykh kommunikatsiy (pp. 134-139). Shchetsin.

Skalinskaya, E. (2011). Dostoyevsky glazami polyakov : O knige Mareka Vedemana "Polonofil ili polonofob? Fedor Dostoyevsky v pol'skoy slovesnosti. 1847-1897" [Dostoyevsky through the Eyes of the Poles. On the Book by Marek Wedemann Polonophile or Polonophobe? Fyodor Dostoyevsky in Polish Literature. 1847-1897]. In Novaya Pol'sha, 5. URL: http://www.novpol.ru/index.php?id=1488 (mode of access: 23.01 .2016 ).

Tokarzewski, S. (1912). Katorznicy. 213 p. Warszawa.

Tokarzewski, S. (1918). Siedem lat Katorgi. 240 p.Warszawa.

Tokarzewski (Tokazhevsky), Sh., Kushnikova, M. (Transl.) \& Togulev, V. (Comp., Foreword). (2007). Sibirskoe likholet'e [Siberian Hard Times]. 980 p. Kemerovo, Kuzbassvuzizdat.

Ungureanu, R. (n. d.). Russian Imperial Presence in Literature. URL: http://www.ruf. rice.edu/ sarmatia/407/272ungure.html (mode of access: 23.01.2016).

Wedemann, M. (2010). Polonofil czy polakozerca? Fiodor Dostojewski w pismiennictwie polskim lat 1847-1897 (pp. 23-29). Poznan, Wydawnichwo Poznanskie.

Zhikharev, S. P. \& Eykhenbaum, B. M. (Ed.). (1955). Zapiski sovremennika [Notes of a Contemporary]. 836 p. Moscow, Leningrad, Izd-vo AN SSSR.

The article was submitted on 26.05.2016 